\section{Adrenocorticotrophic hormone, cortisol and catecholamine concentrations during insulin hypoglycaemia in dogs anaesthetized with thiopentone}

Carlos F. Reyes Toso MD, Ricardo R. Rodríguez MD, Aurora R. Renauld PhD, Adrian G. Márquez AnD, Laura M. Linares MD
Glucose homeostasis is maintained by complex neuroendocrine control mechanisms. Increases in plasma concentrations of various glucose-raising hormones such as glucagon, catecholamines, adrenocorticotrophic hormone (ACTH), and cortisol are observed under certain conditions associated with stress (haemorrhage and hypoglycaemia). The purpose of this study was to determine the effect of thiopentone anaesthesia on the cathecholamine, ACTH and cortisol response to insulin hypoglycaemia in dogs. Blood sugar (BS), plasma cathecholamine, and $A C T H$, and serum cortisol concentrations were measured during the course of (I) an intravenous insulin test (ITT) and (2) an ACTH test in conscious and in anaesthetized fasted dogs. During the ITT, the anaesthetized dogs showed a moderate resistance, compared with conscious dogs, to the hypoglycaemic action induced by insulin (blood sugar concentration $30 \mathrm{~min}$ after insulin injection: $2.91 \pm 0.25$ vs $1.93 \pm 0.12 \mathrm{mM} \cdot \mathrm{L}^{-1}$;

\section{Key words}

ANAESTHETICS, INTRAVENOUS: thiopentone;

ANAESTHETIC TECHNIQUES: intravenous;

METABOLISM: glucose;

HORMONES: adrenocorticotrophic, catecholamines, cortisol, insulin.

From the Department of Physiology, Buenos Aires University Medical School, Buenos Aires, Argentina.

This work was partly supported by the National Board of Scientific and Technical Research (CONICET), Res. Grant N ${ }^{\circ}$ PID E 949/86.

Address correspondence to: Dr. Carlos F Reyes Toso,

Departamento de Fisiología, Facultad de Medicina,

Universidad de Buenos Aires, Paraguay 2155, Piso $7^{\circ}, 1121$,

Buenos Aires, Argentina

Accepted for publication 16th July, 1993.
$P<0.01$ ). In addition, decreased epinephrine (220 \pm 27 vs $\left.332 \pm 32 \mathrm{pg} \cdot \mathrm{ml}^{-1}\right), A C T H\left(65 \pm 6 \cdot \mathrm{vs} 90 \pm 5 \mathrm{pg} \cdot \mathrm{ml}^{-1}\right)$ and cortisol ( $\left.4.48 \pm 0.3 \mathrm{vs} 6.25 \pm 0.5 \mu \mathrm{g} \cdot \mathrm{ml}^{-1}\right)$ concentrations were detected 60 min after insulin injection $(P<0.01)$. The norepinephrine response to hypoglycaemia was not altered by anaesthesia $\left(273 \pm 33 \mathrm{vs} 325 \pm 25 \mathrm{pg} \cdot \mathrm{ml}^{-1}\right)$. Anaesthetized dogs showed a decreased cortisol response to ACTH at $45 \mathrm{~min}$ $\left(5.68 \pm 0.54\right.$ vs $\left.8.87 \pm 0.47 \mu \mathrm{g} \cdot \mathrm{ml}^{-1}\right)$ when compared with control dogs $(P<0.001)$. Haemodynamic variables during anaesthesia showed little changes $(P<N S$ ); while respiratory rate was altered $(P<0.01$ between 60 and $105 \mathrm{~min}$ ). Arterial pH was decreased $(7.29 \pm 0.03$ vs $7.36 \pm 0.04 ; P<0.05)$ and $\mathrm{PaCO}_{2}$ was increased (6.8 \pm 0.3 vs $5.2 \pm 0.3 ; P<0.01$ ) at $30 \mathrm{~min}$ from induction of anaesthesia but little change was seen after the beginning of the ITT and ACTH tests. We conclude that thiopentone anaesthesia provokes a moderate resistance to the hypoglycaemic action of insulin. This does not appear to be related to increases in plasma concentrations of cathecholamines, cortisol or ACTH. Since the hyperglycaemic effects of cathecholamines and glucagon are synergistic it is possible that glucagon plays an important role in the altered blood sugar response to insulin administration.

Lhoméostase du glucose sanguin est maintenue par des mécanismes de contrôle neuroendocriniens complexes. On observe une augmentation des concentrations plasmatiques (ou sériques) de plusieurs hormones hyperglycémiantes telles que le glucagon, l'ACTH et le cortisol sous certaines conditions liées au stress chirurgical comme l'hémorragie et l'hypoglycémie. Le but principal de cette étude est de déterminer les effets de l'anesthésie au thiopental sur la réponse, à l'hypoglycémie insulinique, des catécholamines, de l'ACTH et du cortisol. On détermine la glycémie et les concentrations plasmatiques des catécholamines et de l'ACTH, et les niveaux sériques du cortisol pendant 1) le test de tolérance à l'insuline, 2) l'épreuve à l'ACTH chez des chiens éveillés et anesthésiés. Lorsqu'on compare les chiens 
anesthésiés avec les chiens éveillés, on constate que linjection iv dinsuline provoque sur des mesures aux 30 minutes une insulino-résistance (glycémie: $2,91 \pm 0,25$ vs $1,93 \pm 0,12$ $\left.\mathrm{mM} \cdot \mathrm{L}^{-1} ; P<0,01\right)$ et une baisse de concentration plasmatique mesurée aux 60 minutes de l'épinéphrine $(220 \pm 27$ vs $\left.332 \pm 32 \mathrm{pg} \cdot \mathrm{ml}^{-1}\right)$, de l'ACTH (65 $\left.\pm 6 \mathrm{vs} 90 \pm 5 \mathrm{pg} \cdot \mathrm{ml}^{-1}\right)$ et du cortisol $\left(4,48 \pm 0,3\right.$ vs 6,25 $\left.\pm 0,5 \mu \mathrm{g} \cdot \mathrm{ml}^{-1}\right)(P<0,01)$. $L a$ réponse de la norépinéphrine plasmatique n'est pas modifiée par l'anesthésie $\left(273 \pm 33\right.$ vs $\left.325 \pm 25 \mathrm{pg} \cdot \mathrm{ml}^{-1}\right)$. Quarantecing minutes après l'injection iv d'ACTH, on constate chez les chiens anesthésiés une diminution de la réponse au cortisol $(5,68 \pm 0,54$ vs $8,87 \pm 0,47)$ comparativement aux contrôles $(P<0,001)$. Les paramètres hémodynamiques pendant l'anesthésie demeurent inchangés $(P<N S)$. Par contre, la fréquence respiratoire change $(P<0,01$ entre 60 et $105 \mathrm{~min})$. Trente minutes après l'induction de l'anesthésie, le pH artériel diminue $(7,29 \pm 0,03$ vs 7,36 $\pm 0,04: \mathrm{P}<0,05)$, la $\mathrm{PaCO}_{2}$ augmente $(6,8 \pm 0,3$ vs $5,2 \pm 0,3 ; P<0,01)$. On note peu de changements après le début des test de tolérance au glucose et l'épreuve à l'ACTH. A partir de ces données on peut conclure que l'anesthésie au thiopental produit une insulino-résistance modérée. Cet effet ne résulte pas d'une augmentation plasmatique des catécholamines, de l'ACTH ou du cortisol. Au contraire, le niveau sanguin de ces hormones diminue. On énonce comme postulat lintervention probable du glucagon dans les mécanismes de régulation aigus de la glycémie chez les chiens anesthésiés.

Increases in plasma concentrations of glucose-raising factors such as glucagon, catecholamines, ACTH, and cortisol are associated with stress (haemorrhage and hypoglycaemia)..$^{1-5}$ During haemorrhagic hypotension, hyperglycaemia is mainly due to an increase in circulating catecholamines and not to glucagon secretions. ${ }^{6,7}$ On the contrary, during progressive and sustained hypoglycaemia induced by insulin, plasma glucose concentration decreases and the spontaneous correction of the hypoglycaemia is by the combined effects of glucagon, catecholamines and, to a lesser extent, cortisol through activation of the hypothalamic-pituitary-adrenal axis. ${ }^{8-10}$

Previous reports using the concentration of plasma catecholamines as a quantitative index of sympathetic stimulation suggested that barbiturate anaesthesia had no effect on sympathetic tone. ${ }^{11,12}$ However, studies using a more sensitive and specific radioenzymatic assay for plasma catecholamines ${ }^{13}$ showed that barbiturates decreased circulating levels of these hormones in stressed animals. ${ }^{14}$ Furthermore previous in vitro evidence indicated that pentobarbitone inhibited catecholamine secretion in perfused bovine adrenal glands. ${ }^{15}$

In addition, thiopentone-nitrous oxide anaesthesia either had no effect ${ }^{16,17}$ or had a depressant activity ${ }^{18}$ on plasma cortisol concentrations. However, interpretation of some of the clinical observations was complicated by the potential interaction of the barbiturates with the other anaesthetic agents employed after induction of anaesthesia. ${ }^{19}$

The present work, in dogs, was undertaken to determine whether thiopentone infusion is capable of modifying the plasma concentrations of some of the hormones that are released to restore normal blood sugar concentrations in response to insulin-induced hypoglycaemia.

\section{Methods}

\section{Animals}

Twenty-four disinfested, male mongrel dogs, weighing $15-21 \mathrm{~kg}$, fed on dog chow pellets and water ad libitum, were used in the experiments. Their use was approved by the Animal Research Committee, Department of Physiology, Medical School, University of Buenos Aires, Argentine.

The dogs were kept in individual cages in an animal room of the department, under normal conditions of feeding for four weeks before the tests were performed. Meanwhile, they were transferred into the laboratory for one hour daily, for adaptation to new surroundings and the continuous presence of people. During the week preceding the tests, every animal was checked for several biological variables, including blood sedimentation rate, haematocrit, haemoglobin and blood sugar concentrations. The dogs employed in the experiments had no clinical or biochemical evidence of disease.

On the day of the experiment, every dog was tested after fasting (18-22 hr). Only normothermic animals were used (rectal temperatures $<37.8^{\circ} \mathrm{C}$ ). Twelve animals were kept as conscious, unrestrained controls, while the other 12 dogs were anaesthetized one hour before the tests. Dogs were placed in each group at random. Anaesthesia was induced with thiopentone $\left.12 \mathrm{mg} \cdot \mathrm{kg}^{-1} \dot{i v}\right)$ and was maintained with the same anaesthetic agent by continuous iv infusion $\left(20-25 \mathrm{mg} \cdot \mathrm{kg}^{-1} \cdot \mathrm{hr}^{-1}\right)$. Six of the anaesthetized dogs were submitted to an ACTH test.

The tracheas were intubated with cuffed endotracheal tubes and the dogs were allowed to breathe spontaneously. To avoid hypoventilation, breathing was assisted periodically just after the induction of anaesthesia with positive-pressure ventilation with room air, in accordance with the results of clinical observation of respiratory effort and arterial blood gas analysis. An 18-ga teflon needle was inserted into a femoral artery in the anaesthetized dogs to measure the mean arterial pressure via a damped anaeroid manometer. Subsequently, another cannula, 
used for thiopentone injection, was inserted into a leg vein to maintain anaesthesia. During the two hours after induction of anaesthesia the mean blood pressure, heart and respiratory rates were measured every $15 \mathrm{~min}$, while blood samples were taken anaerobically from the femoral artery before and at $30,60,90$ and $120 \mathrm{~min}$ from induction for estimation of $\mathrm{pH}, \mathrm{PaO}_{2}, \mathrm{PaCO}_{2}$, haematocrit and plasma bicarbonate concentration. The thiopentone concentration was measured in blood samples taken by venipuncture at the same times.

In conscious dogs an 18-ga teflon needle was inserted under local anaesthesia into a femoral artery to measure the initial mean arterial pressure, one hour before the beginning of the experiments, and then was removed. Afterwards the animals received a catheter by venipuncture in a leg vein, and $60 \mathrm{~min}$ later the experiments began.

\section{Experimental design}

The 24 dogs were grouped randomly as follows:

1 Study of the action of thiopentone anaesthesia on blood sugar concentration, serum cortisol and plasma concentrations of $\mathrm{ACTH}$, norepinephrine and epinephrine in six conscious and six anaesthetized dogs during an $\dot{N}$ insulin tolerance test (ITT).

2 Study of the action of thiopentone anaesthesia on blood sugar concentration and serum cortisol in six conscious and six anaesthetized dogs during an ACTH $i v$ test.

\section{Tests}

The ITT consisted of a glucagon-free insulin injection, Lilly Laboratories, Argentine $\left(0.25 \mathrm{IU} \cdot \mathrm{kg}^{-1}\right.$ iv in $5 \mathrm{ml}$ saline).

Blood samples $(3 \mathrm{ml})$ were taken every $15 \mathrm{~min}$ during the first hour of the study and before the insulin injection, and then at 15,20,25,30,35, 45 and $60 \mathrm{~min}$ of the beginning of ITT. A polyethylene catheter, inserted into the foreleg vein, was used for blood withdrawal. The ACTH test consisted of ACTH (Elea Laboratories, $\mathrm{Ar}$ gentine), $i v$ injection (25 IU ACTH in $5 \mathrm{ml}$ saline). Blood samples were taken every $15 \mathrm{~min}$ during the first hour of the study and before ACTH injection, and then at 30 and $45 \mathrm{~min}$. Blood samples were collected with a plastic syringe containing $100 \mathrm{IU}$ of heparin. A small portion of blood was used for blood sugar determination while the rest was transferred to ice-cold plastic tubes and, after centrifugation, the plasma was separated and stored at $-40^{\circ} \mathrm{C}$ for ACTH or catecholamine assays. The other blood sample was used to obtain serum for cortisol assay after allowing blood to clot at room temperature for one hour, followed by centrifugation $(5 \mathrm{~min}, 2500 \mathrm{rpm}$ ) and storage at $-40^{\circ} \mathrm{C}$ until measurement.

Each blood sample was replaced with $3 \mathrm{ml}$ of normal Ringer's lactate solution.
Assays

Arterial blood samples were analyzed for $\mathrm{pH}, \mathrm{PaCO}_{2}$ and $\mathrm{PaO}_{2} \cdot{ }^{20} \mathrm{Blood}$ was assayed for thiopentone according to the method of Jailer and Goldbaum, modified by Goldbaum (minimal detectable concentration: 1.5 $\mu \mathrm{g} \cdot \mathrm{ml}^{-1}{ }^{21,22}$ Blood sugar concentration was measured in a Technicom Autoanalizer, ${ }^{23}$ and ACTH and cortisol were determined using commercially available kits ( $\mathrm{Di}$ agnostic Products Corporation, Los Angeles). The reliability of cortisol and ACTH procedures were assayed by examining the reproducibility on samples selected to represent the spectrum of low, normal and elevated levels of circulating cortisol and ACTH. The minimal detectable concentrations of cortisol and ACTH were approximately $0.2 \mu \mathrm{g} \cdot \mathrm{ml}^{-1}$ and $7 \mathrm{pg} \cdot \mathrm{ml}^{-1}$ respectively.

Plasma catecholamine concentrations were assayed by the catechol-O-methyl-transferase radioenzymatic method $^{24}$ with slight modifications. ${ }^{25}$ The assay was found to be linear up to $1 \mathrm{ng}$ per tube of each of the two amines. The interassay variation coefficients were $15 \%$ and $16 \%$ for epinephrine and norepinephrine respectively.

\section{Statistical evaluation}

The estimations of blood pressure, of heart and respiratory rates, and the values of $\mathrm{pH}, \mathrm{PaCO}_{2}, \mathrm{PaO}_{2}$ and thiopentone concentration in the anaesthetized dogs were compared by ANOVA for repeated measures. NewmanKeuls multiple comparison test was used after analysis of variance. ${ }^{26}$

A three factor (treatment, time and block) ANOVA was used to study results from the ITT and ACTH tests. ${ }^{27}$

\section{Results}

Biological data of the dogs employed in the experiments The data were obtained the week preceding the tests, during the laboratory analysis carried out in the dogs which were to be employed in the experiments.

The mean $( \pm \mathrm{SEM})$ blood sedimentation rate was ? $\pm 4 \mathrm{~mm} \cdot \mathrm{hr}^{-1}$; haemoglobin concentration $13 \pm 2$ $\mathrm{g} \cdot \mathrm{dl}^{-1}$; haematocrit $44 \pm 3 \mathrm{ml} \cdot \mathrm{dl}^{-1}$; and blood sugar concentration was $3.6 \pm 0.4 \mathrm{mM} \cdot \mathrm{L}^{-1}$.

\section{Thiopentone anaesthetized dogs}

Heart rate and arterial blood pressure showed little change during the study, while respiratory rate was decreased by thiopentone anaesthesia $(P<0.01)$ (Table I).

Arterial $\mathrm{pH}$ was decreased and $\mathrm{PaCO}_{2}$ increased 30 min after induction of anaesthesia $(P<0.05$ and $P<$ 0.01 ). Plasma bicarbonate concentration was not affected. Thiopentone plasma concentration did not change (Table II). 
TABLE I Influence of thiopentone anaesthesia on haemodynamic variables and respiratory rate in normal dogs. Insulin and ACTH were injected $i v$ just after $60 \mathrm{~min}$ (mean $\pm \mathrm{SEM}$ ). Statistical analysis: ANOVA for repeated measures. Group $A=I T T, B=A C T H$ test.

\begin{tabular}{|c|c|c|c|c|c|c|c|c|c|c|}
\hline \multirow[b]{2}{*}{ Variables } & & \multirow{2}{*}{$\begin{array}{l}\text { Conscious } \\
0\end{array}$} & \multicolumn{8}{|c|}{ Anaesthetized - time after induction of anaesthesia (min) } \\
\hline & & & 15 & 30 & 45 & 60 & 75 & 90 & 105 & 120 \\
\hline $\begin{array}{l}\text { Heart rate } \\
\text { bpm }\end{array}$ & $\begin{array}{l}\text { A } \\
\text { B }\end{array}$ & $\begin{array}{l}119 \pm 5 \\
120 \pm 6\end{array}$ & $\begin{array}{l}110 \pm 4 \\
113 \pm 7\end{array}$ & $\begin{array}{l}113 \pm 4 \\
116 \pm 4\end{array}$ & $\begin{array}{l}111 \pm 6 \\
112 \pm 5\end{array}$ & $\begin{array}{l}115 \pm 7 \\
119 \pm 3\end{array}$ & $\begin{array}{l}113 \pm 5 \\
115 \pm 6\end{array}$ & $\begin{array}{l}105 \pm 2 \\
111 \pm 3\end{array}$ & $\begin{array}{l}108 \pm 4 \\
116 \pm 5\end{array}$ & $\begin{array}{l}114 \pm 7 \\
113 \pm 3\end{array}$ \\
\hline $\begin{array}{l}\text { Blood pressure } \\
\text { KPa }\end{array}$ & $\begin{array}{l}\text { A } \\
\text { B }\end{array}$ & $\begin{array}{r}17.5 \pm 0.9 \\
18 \pm 1.2\end{array}$ & $\begin{array}{r}17 \pm 1.1 \\
16.8 \pm 0.9\end{array}$ & $\begin{array}{l}16.7 \pm 0.9 \\
16.4 \pm 1\end{array}$ & $\begin{aligned} 17 & \pm 0.9 \\
16.5 & \pm 1\end{aligned}$ & $\begin{array}{l}16.3 \pm 1 \\
17 \pm 0.8\end{array}$ & $\begin{array}{l}16.9 \pm 1 \\
16.8 \pm 1.2\end{array}$ & $\begin{array}{l}17.2 \pm 0.8 \\
16.5 \pm 1\end{array}$ & $\begin{array}{l}16.8 \pm 1.1 \\
17.3 \pm 0.9\end{array}$ & $\begin{array}{l}16.3 \pm 0.9 \\
17.5 \pm 1.3\end{array}$ \\
\hline $\begin{array}{l}\text { Resp. rate } \\
\text { bpm }\end{array}$ & $\begin{array}{l}\text { A } \\
\text { B }\end{array}$ & $\begin{array}{l}23 \pm 4 \\
21 \pm 2\end{array}$ & $\begin{array}{l}10 \pm 2^{*} \\
12 \pm 3^{*}\end{array}$ & $\begin{array}{l}12 \pm 2 \dagger \\
15 \pm 2 \ddagger\end{array}$ & $\begin{array}{l}11 \pm 3 \dagger \\
16 \pm 4 \ddagger\end{array}$ & $\begin{array}{l}13 \pm 3 \dagger \\
12 \pm 3 \dagger\end{array}$ & $\begin{array}{l}14 \pm 3 \dagger \\
12 \pm 3 \dagger\end{array}$ & $\begin{array}{l}11 \pm 3 \dagger \\
14 \pm 1 \dagger\end{array}$ & $\begin{array}{l}13 \pm 3 \dagger \\
12 \pm 4 \dagger\end{array}$ & $\begin{array}{l}16 \pm 1 \ddagger \\
13 \pm 2 \dagger\end{array}$ \\
\hline
\end{tabular}

$* P<0.001 ; \dagger P<0.01 ; \ddagger P<0.05$ anaesthetized vs conscious dogs.

TABLE II Blood $\mathrm{pH}, \mathrm{PaO}_{2} / \mathrm{PaCO}_{2}$, bicarbonate and thiopentone concentrations in normal dogs. Anaesthesia was induced at time 0 (mean \pm SEM). Repeated measures ANOVA. Conscious. Number of animals: $=12$.

\begin{tabular}{lccccc}
\hline & \multicolumn{4}{l}{ Anaesthetized - time after induction of anaesthesia (min) } \\
\cline { 2 - 6 } Variable & Conscious & 30 & 60 & 90 & 120 \\
\hline $\mathrm{pH}$ & $7.36 \pm 0.04$ & $7.29 \pm 0.03^{*}$ & $7.32 \pm 0.03$ & $7.33 \pm 0.03$ & $7.36 \pm 0.04$ \\
$\mathrm{PaO}_{2}(\mathrm{KPa})$ & $11.8 \pm 0.5$ & $10.3 \pm 0.3$ & $10.9 \pm 0.5$ & $10.7 \pm 0.5$ & $11.3 \pm 0.5$ \\
$\mathrm{PaCO}_{2}(\mathrm{KPa})$ & $5.2 \pm 0.3$ & $6.8 \pm 0.3 \dagger$ & $5.5 \pm 0.2$ & $5.7 \pm 0.3$ & $6.5 \pm 0.3^{*}$ \\
Bicarbonate $\left(\mathrm{mmol} \cdot \mathrm{L}^{-1}\right)$ & $23 \pm 2$ & $20 \pm 2$ & $20 \pm 2$ & $22 \pm 1$ & $24 \pm 2$ \\
Thiopentone $\left(\mu \mathrm{g} \cdot \mathrm{ml}^{-1}\right.$ & - & $34.1 \pm 3$ & $38.8 \pm 3$ & $37.9 \pm 3$ & $35.3 \pm 3$ \\
\hline
\end{tabular}

$* P<0.05 ; \nmid P<0.01:$ anaesthetized vs conscious dogs.

\section{Hormonal response to ITT in anaesthetized dogs}

After insulin administration a rapid decrease in blood sugar concentrations occurred and caused hypoglycaemia in both groups of dogs $(P<0.01)$, but was less intense in the anaesthetized group $(P<0.01$, Figure 1$)$.

Norepinephrine and epinephrine concentrations did not differ from controls after one hour of thiopentone anaesthesia. Both catecholamines increased during ITT $(P<$ 0.05 for norepinephrine and $P<0.001$ for epinephrine at $60 \mathrm{~min}$, Figure 2). The increase in plasma epinephrine concentration was less in the anaesthetized than in the conscious dogs $(P<0.01)$.

After one hour of anaesthesia, ACTH and cortisol concentrations remained unchanged compared with preinduction values. The ACTH response to hypoglycaemia was observed in conscious and anaesthetized dogs $(P<$ 0.001 , Figure 3 ), but was greater in the control group $(P<0.01)$. The pattern of serum cortisol response to ITT was similar to that of plasma ACTH, although maximal concentrations were achieved at $60 \mathrm{~min}$ (Figure 3).

\section{Hormonal response to ACTH test in anaesthetized dogs} Blood glucose concentrations were similar to pre-injection values in both groups (Figure 4). There were no differences in blood sugar concentrations between control and anaesthetized dogs.
Serum cortisol concentrations were increased during the ACTH test in both groups $(P<0.001)$ (Figure 4) and the increase was more pronounced in control than in anaesthetized dogs $(P<0.001)$.

\section{Discussion}

Hepatic glucose metabolism, endocrine pancreatic secretion and adrenal medullary secretion are regulated by several mechanisms under the control of the automatic nervous system. Under certain conditions associated with stress, such as haemorrhage or hypoglycaemia, increases in plasma concentrations of various glucose-raising (counter-regulatory hormones) occur. Glucose intolerance during thiopentone anaesthesia is well documented and has been described in a previous experimental study. ${ }^{28}$ The moderate resistance to insulin found in that report may have been due to an alteration in the distribution space and serum clearance of insulin

Thiopentone anaesthesia markedly decreased the hypoglycaemic response to insulin in these dogs in whom surgery was deliberately excluded. ${ }^{29}$ Furthermore, the haemodynamic and acid-base variables, which are known to be responsible for alterations in carbohydrate metabolism, ${ }^{30}$ did not influence the results, because they did not change during most of the period (60 to $105 \mathrm{~min}$ ) in which ITT and ACTH tests were carried out. A de- 

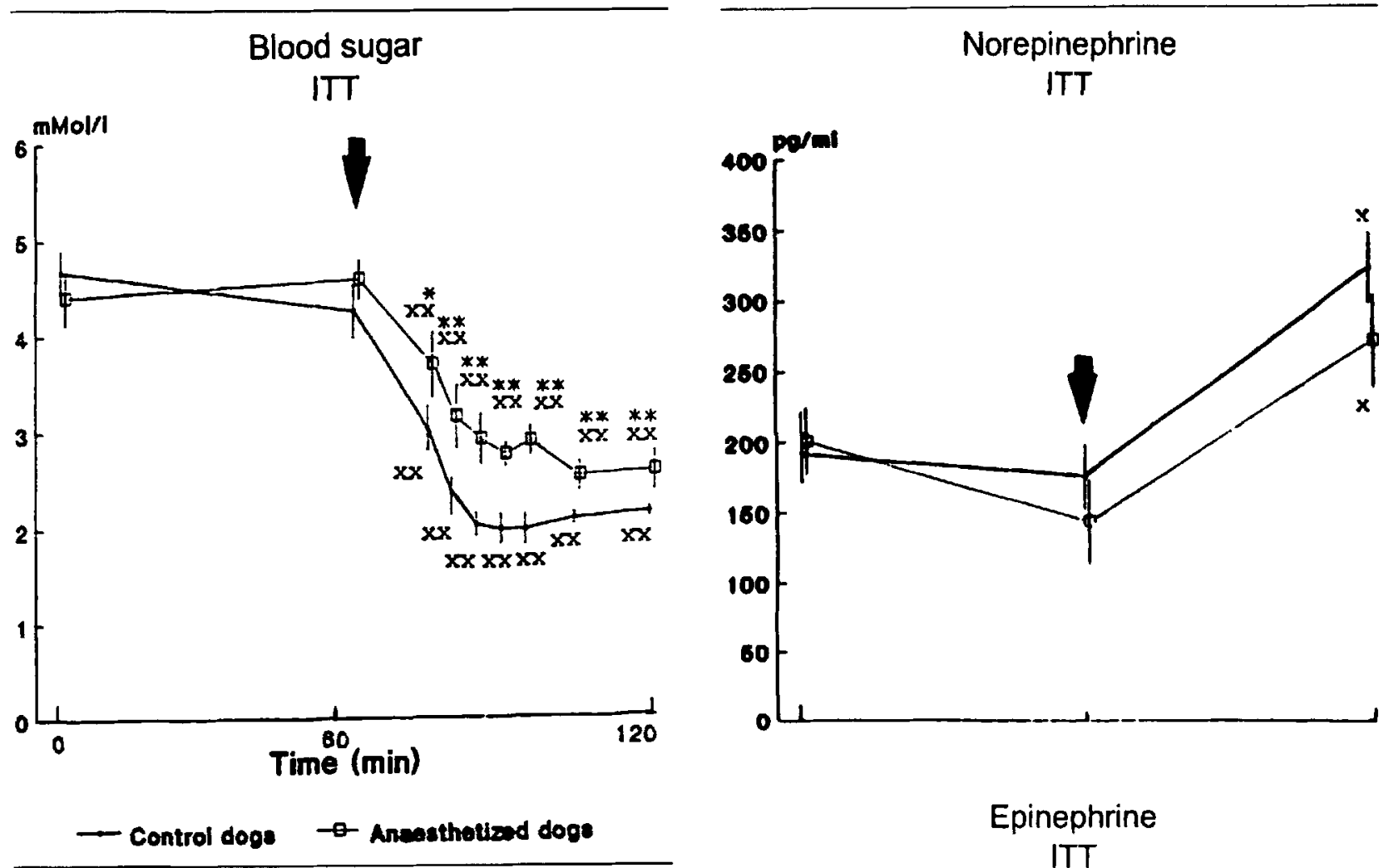

FIGURE 1 Effect of thiopentone anaesthesia on changes in blood sugar concentration during $i v$ insulin tolerance test in dogs. $\mathrm{xx}: P<$ 0.01 times vs $\mathrm{t}=0 ;{ }^{*},{ }^{* *}: P<0.05, P<0.01$ anaesthetized vs conscious.

crease in arterial $\mathrm{pH}$ and an increase in $\mathrm{PaCO}_{2}$ were detected only $30 \mathrm{~min}$ before the beginning of the tests. This acidosis and hypercarbia did not modify the basal values of catecholamines, ACTH or cortisol measured $60 \mathrm{~min}$ after the beginning of the experiments. A mild hypercarbia was then observed at the end of the experimental period (120 min).

The decreased hypoglycaemic response to insulin administration in anaesthetized dogs was accompanied by lower circulating epinephrine, ACTH and cortisol concentrations than in conscious dogs.

Blood concentrations of epinephrine, glucagon, growth hormone, ACTH and cortisol are increased by hypoglycaemia in the normal conscious dog. ${ }^{31}$ Both glucagon and epinephrine are potent stimulators of hepatic glycogenolysis and gluconeogenesis, under the permissive action of cortisol, resulting in a transient increase in hepatic glucose production. The effect of growth hormone usually requires several hours to occur and, therefore, the release of this hormone is unlikely to be critical to a rapid increase of plasma glucose concentration. ${ }^{32}$

Our results showed that epinephrine, ACTH and cortisol concentrations are decreased in dogs anaesthetized with thiopentone compared with conscious controls.

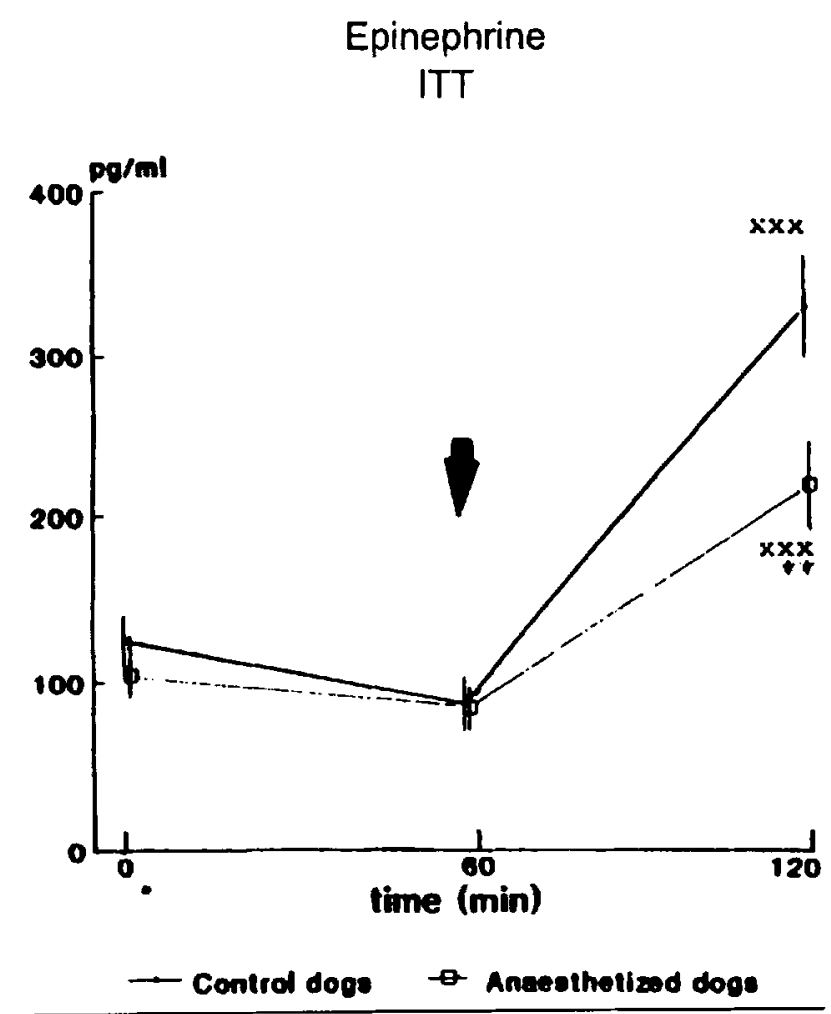

FIGURE 2 Effect of thiopentone anaesthesia on changes in plasma catecholamine concentrations during $i v$ insulin tolerance test in dogs. $\mathrm{x}$, xxx: $P<0.05, P<0.001$ times vs $\mathrm{t}=0$; **: $P<0.01$ anaesthetized vs conscious.

A stimulus-response relationship exists between the decrease in blood sugar and the increase in plasma con- 


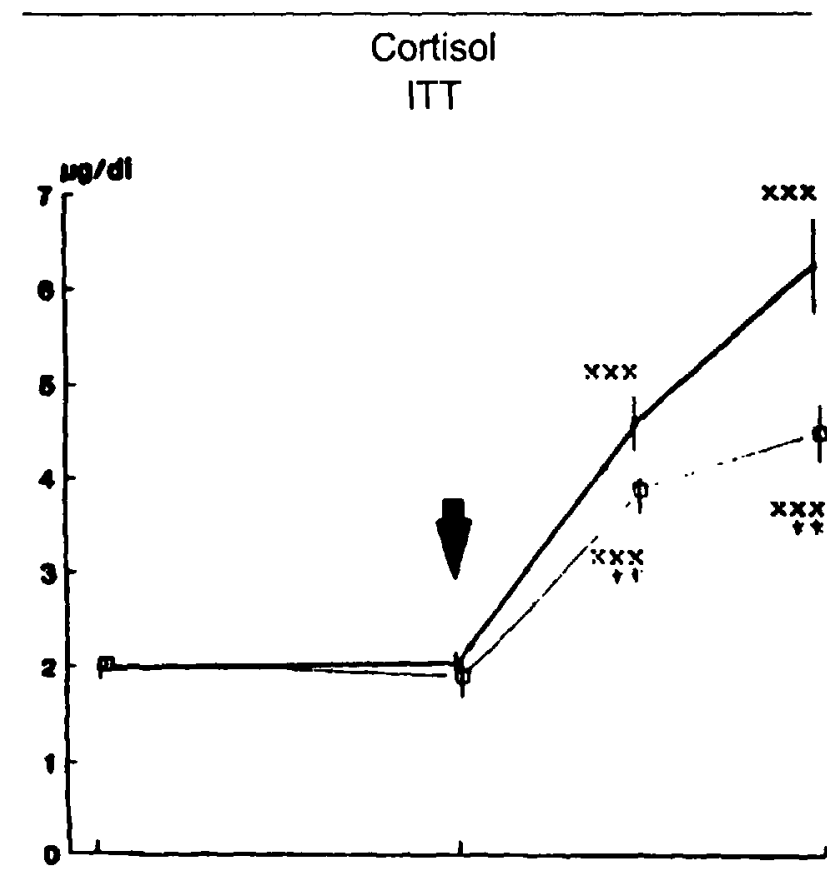

Cortisol
ACTH

\section{ACTH}

ITT

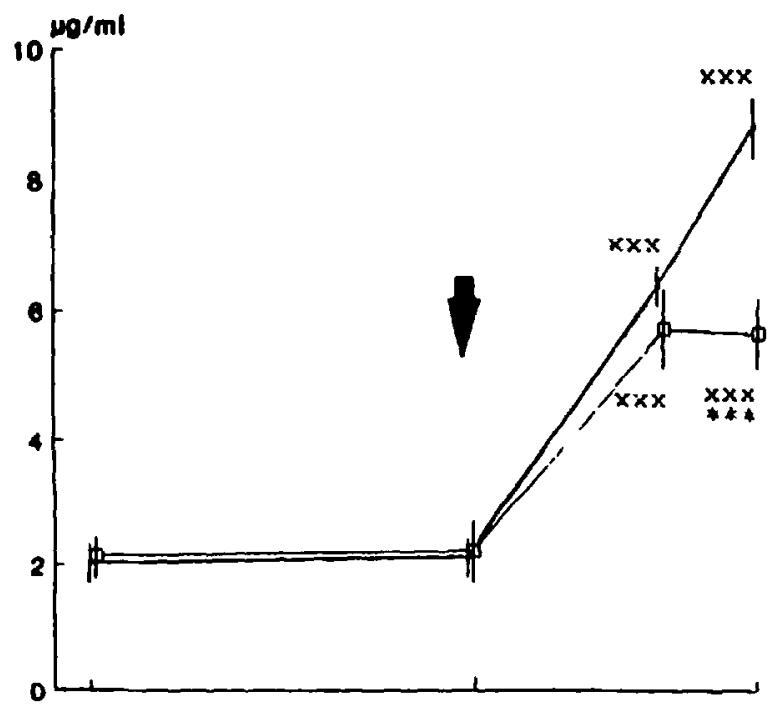

Blood sugar

ACTH
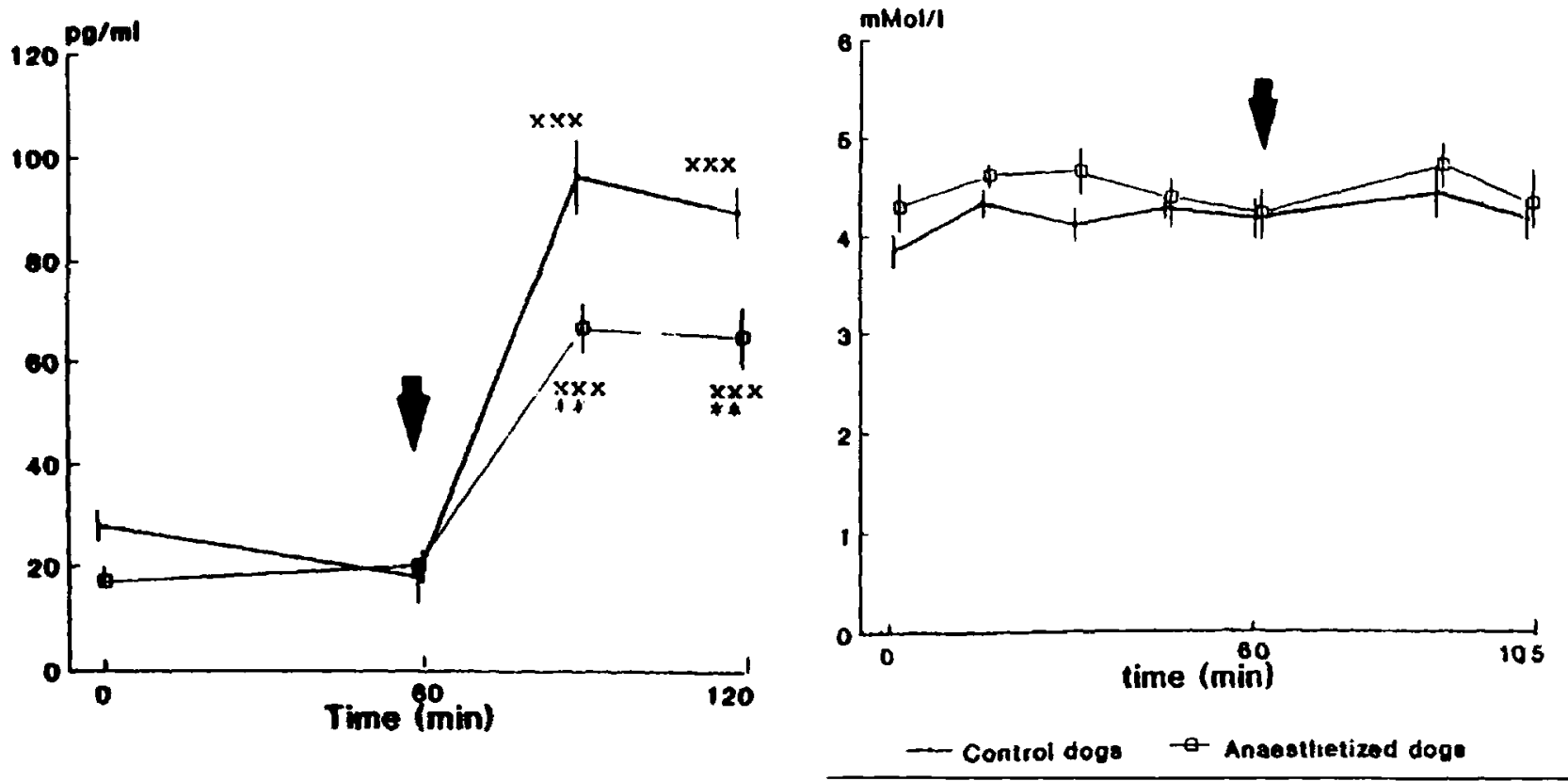

FIGURE 4 Effect of thiopentone anaesthesia on changes in blood sugar and serum cortisol concentrations during iv ACTH test in dogs. xxx: $P<0.001$ times vs $\mathrm{t}=0 ; * * *: P<0.001$ anaesthetized vs conscious.

FIGURE 3 Effect of thiopentone anaesthesia on changes in plasm ACTH and serum cortisol concentrations during $i v$ insulin tolerance test in dogs. xxx: $P<0.001$ times vs $\mathrm{t}=0 ;{ }^{* *}: P<0.01$ anaesthetized vs conscious.

centrations of ACTH-cortisol and catecholamines. ${ }^{33,34}$ The relationship between the nadir in glycaemia and the

peak in the hormonal response is a continuous function with a threshold at $2.2 \mathrm{mM} \cdot \mathrm{L}^{-1}$. In conscious dogs, blood sugar concentrations lower than that were obtained 
30 min after $\dot{v}$ insulin injection, while in anaesthetized animals higher values were observed $\left(2.8 \mathrm{mM} \cdot \mathrm{L}^{-1}\right.$. Thus, it could be argued that the decreased hypoglycaemic response observed in the anaesthetized dogs could have been responsible for the altered ACTH-cortisol response observed. However, this assumption does not seem to be in accordance with experimental data obtained from the ACTH $i v$ test which suggest that, in spite of similar blood sugar concentrations, thiopentone anaesthetized dogs had an altered cortisol response to iv ACTH administration. The decreased cortisol response to ACTH shows that the inhibitory effect of thiopentone on plasma cortisol concentration is exerted at least partially at the adrenal gland. The observation that thiopentone partially suppresses the response of epinephrine to insulin hypoglycaemia is consistent with other evidence demonstrating that barbiturates decrease the concentration of catecholamines in plasma. ${ }^{35,36}$ Clinically, this is important in stressed hypovolaemic patients, due to the role of circulating catecholamines in the regulation of blood pressure.

The present report suggests that thiopentone provokes a moderate resistance to the hypoglycaemic action of insulin (when insulin availability is high). This effect does not appear to be related to increases in plasma concentrations of catecholamines, cortisol or ACTH. However, it is possible that glucagon plays an important role in the altered response observed, but further studies are needed to clarify the mechanisms involved.

The implications of this study are that experimental data derived from tests performed under anaesthesia should be interpreted in the light of the effects of thiopentone anaesthesia alone, and that such effects are independent of surgical stress and are not complicated by the additional influences of drugs used for premedication, induction and maintenance of anaesthesia. These results may help the selection of the most suitable anaesthetic for patients in whom the metabolic effects of the anaesthetic agent could be important.

\section{Acknowledgements}

The authors are grateful to Dr. Marta Barontini, Endocrinologic Center, R. Gutierrez Children's Hospital, Buenos Aires, for the radioenzymatic determination of catecholamines in plasma; and to Dr. Jorge Pinto for his assistance in reviewing this manuscript. We also thank the able technical assistance of Mrs. Irene Villarreal.

\section{References}

1 Cryer PE, Gerich JE. Glucose counterregulation, hypoglycaemia, and intensive insulin therapy in diabetes mellitus. N Engl J Med 1985; 313: 232-41.

2 Briand R, Yamaguchi N, Gagne J. Plasma catecholamine and glucose concentrations during hemorrhagic hypoten- sion in anesthetized dogs. Am J Physiol 1989; 257:

R317-25.

3 Smythe GA, Pascoe WS, Storlien LH. Hypothalamic noradrenergic and sympathoadrenal control of glycaemia after stress. Am J Physiol 1989; 256: E231-5.

4 Briand R, Gagne J, Yamaguchi N. Pancreatic glucagon secretion during a short period of hemorrhage in anesthetized dogs. Can J Physiol Pharmacol 1990; 68: 814-9.

5 Vigas $M$, Tatar $P$, Jurcovicova J, Jezova $D$. Glucoreceptors located in different areas mediate the hypoglycaemiainduced release of growth hormone, prolactin, and adrenocorticotropin in man. Neuroendocrinology 1990; 51: 365-8.

6 Cryer PE, Tse TF, Clutter WE, Shah SD. Roles of glucagon and epinephrine in hypoglycemic and nonhypoglycemic glucose counterregulation in humans. Am J Physiol 1984; 247: E198-205.

7 Saccà $L$. Role of counterregulatory hormones in the regulation of hepatic glucose metabolism. Diabetes Metab Rev 1987; 3: 207-29.

8 Rizza RA, Cryer PE, Gerich JE. Role of glucagon, catecholamines, and growth hormone in human glucose counterregulation. Effects of somatostatin and combined $\alpha$ and $\beta$-adrenergic blockade on plasma glucose recovery and glucose flux rates after insulin-induced hypoglycemia. $J$ Clin Invest 1979; 64: 62-71.

9 Järhult J, Farnebo L-O, Hamberger B, Holst J, Schwartz $T W$. The relation between catecholamines, glucagon and pancreatic polypeptide during hypoglycaemia in man. Acta Endocrinol (Copenh) 1981; 98: 402-6.

10 Hilsted J, Christensen NJ, Larsen S. Norepinephrine kinetics during insulin-induced hypoglycemia. Metabolism: Clinical \& Experimental 1985; 34: 300-20.

11 Price $H L$, Linde $H W$, Jones $R E$, Black GW, Price $M L$. Sympathoadrenal responses to general anesthesia in man and their relation to hemodynamics. Anesthesiology 1959; 20: 563-75.

12 Hamelberg W, Sprouse JH, Mahaffey JE, Richardson JA. Catecholamine levels during light and deep anesthesia. Anesthesiology 1960; 21: 297-302.

13 Da Prada $M$, Zürcher G. Simultaneous radioenzymatic determination of plasma and tissue adrenaline, noradrenaline and dopamine within the fentomole range. Life Sci 1976; 19: 1161-74.

14 Zimpfer M, Manders WT, Barger AC, Vatner SF. Pentobarbitone alters compensatory neural and humoral mechanisms in response to hemorrhage. Am J Physiol 1982; 243: H713-21.

15 Holmes JC, Schneider FH. Pentobarbitone inhibition of catecholamine secretion. Br J Pharmacol 1973; 49: 205-13.

16 Hammond WG, Vandam LD, Davis JM, Carter RD, Ball $M R$, Moore $F D$. Studies in surgical endocrinology IV. Anesthetic agents as stimuli to change in corticosteroids and metabolism. Ann Surg 1958; 148: 199-211. 
17 Vandam LD, Moore FD. Adrenocortical mechanisms related to anesthesia. Anesthesiology 1960; 21: 531-52.

18 Harwood CT. Effect of tranquilizing agents on ACTH secretion. J Clin Endocrinol Metab 1956; 16: 938.

19 Skovsied PM, Price $M L$, Price HL. The effects of shortacting barbiturates on arterial pressure, preganglionic sympathetic activity and barostatic reflexes. Anesthesiology 1970; 33: 10-8.

20 Siggard Andersen $O$, Engel $K$. A new acid-base nomogram. An improved method for the calculation of the relevant blood acid-base data. Scand J Clin Lab Invest 1960; 12: 177-86.

21 Goldbaum LR. An ultraviolet spectrophotometric procedure for the determination of barbiturates. J Pharmacol Exp Therap 1948; 94: 68-75.

22 Goldbaum $L R$. An improved ultraviolet spectrophotometric procedure for the determination and differentiation of barbiturates. Federation Proceedings 1951; 10: 299.

23 Renauld A, Andrade LL, Lindental MS, Garcia B. Micrométodo automatizado para la medición de la glucemia. Estudio comparativo de conservadores. Revista Asociación Bioquímica Argentina 1975; 40: 171-5.

24 Armando I, Levin $G$, Barontini $M$. Evaluation of sympathetic nervous system and adrenomedullary activity in normal children. Journal of the Autonomic Nervous System 1983; 8: 57-63.

25 Pisarev MA, Cardinali DP, Juvenal GJ, Vacas MI, Barontini $M$, Boado $R J$. Role of the sympathetic nervous system in the control of the goitrogenic response in the rat. Endocrinology 1981; 109: 2202-7.

26 Winer BJ. Statistical Principles in Experimental Design (2nd Ed.). New York: McGraw Hill, 1971; 907.

27 Lison $L$. Statistique appliqués à la biologie expérimentale. Paris: Gauthier-Villars Ed. 1958; 85: 92.

28 Reyes Toso CF, Rodríguez $R R$, Renauld A, Sverdlik $R C$, Linares $L M$. Blood sugar, serum insulin and serum nonesterified fatty acid levels during thiopentone anaesthesia in dogs. Can J Anaesteh 1993; 40: 38-45.

29 Makara $G B$. Mechanism by which stressful stimuli activate the pituitary-adrenal system. Federation Proceedings. 1985; 44: 149-53.

30 Adrogué HJ, Chap Z, Okuda Y, et al. Acidosis-induced glucose intolerance is not prevented by adrenergic blockade. Am J Physiol 1988; 255: E812-23.

31 Reyes Toso CF, Rodríguez RR, Renauld AA, Márquez $A G$, Sverdlik $R C$, Linares $L M$. Effect of beta-adrenergic propranolol blocking on hormonal mechanisms of glucose regulation in the dog. Medicina (Buenos Aires) 1991; 51 : 26-32.

32 Cryer PE. Coordinated responses of glucogenic hormones to central glucopenia: the role of the sympathoadrenal system. Advances in Metabolic Disease. 1983; 10: 469-83.
33 Keller-Wood ME, Shinsako J, Keil LC, Dallman MF. Insulin-induced hypoglycaemia in conscious dogs. I. Doserelated pituitary and adrenal responses. Endocrinology 1981; 109: 818-24.

34 Santiago JV, Clarke WL, Shah SD, Cryer PE. Epinephrine, norepinephrine, glucagon, and growth hormone release in association with physiological decrements in plasma glucose concentration in normal and diabetic man. J Clin Endocrinol Metab 1980; 51: 877-83.

35 Roizen MF, Moss J, Henry DP, Weise V, Kopin IJ. Effect of general anesthetics on handling-and decapitationinduced increases in sympathoadrenal discharge. J Pharmacol Exp Ther 1978; 204: 11-8.

36 Armstrong $M$, Lefébre-Borg F, Scatton B, Cavero I. Urethane inhibits cardiovascular response mediated by the stimulation of alpha-2 adrenoceptors in the rat. J Pharmacol Exp Ther 1982; 223: 524-35. 